\title{
PENDIDIKAN ISLAM DALAM PERSPEKTIF Ulama BUgis K.H. LANRE SAID
}

\author{
Muhammad Zaitun Rasmin \\ Wahdah Islamiyah Foundation \\ zaitunrasmin@gmail.com
}

\begin{abstract}
ABSTRAK
Sebagai sebuah usaha untuk melestarikan ajaran pemahaman dan ideologi, pendidikan Islam akan terus eksis selama umat Islam masih menjalankan kewajiban beragama. Dengan pendidikan ajaran agama tetap terjaga, para ulama sebagai agen pendidikan terus muncul tiap saat. Di Indonesia, perkembangan pendidikan Islam cukup pesat, baik sebelum maupun setelah kemerdekaan. Ulama Indonesia yang telah menimba ilmu di luar maupun dalam negeri berlomba mendirikan lembaga pendidikan dengan konsep yang mereka rumuskan. Hasilnya, lahirlah berbagai lembaga pendidikan Islam yang kelak melahirkan tokoh-tokoh bangsa. Tren perkembangan pendidikan Islam yang bermula dari Sumatera, lalu ke Jawa, akhirnya ke Sulawesi Selatan. Di kepulauan ini, berdiri beberapa lembaga pendidikan kaderisasi ulama, khususnya ulama Bugis. Ulama Bugis telah membuktikan bahwa mereka tetap eksis dengan perubahan zaman yang begitu cepat. Merespons dengan baik setiap pergantian zaman, tetap menjadi bagian penting dalam membangun bangsa lewat dunia pendidikan dengan mencerdaskan kehidupan bangsa, membangun masyarakat beradab. Mereka pada akhirnya menjadi agen islamisasi di wilayah Indonesia Timur pada paruh kedua abad ke-XX. Di antara ulama terkemuka Bugis adalah Lanre Said. Beliau telah meletakkan dasar-dasar pemikiran pendidikan Islam di nusantara terkhusus masyarakat Bugis, terutama pendidikan Tahfidzul Qur'an. Dengan hidupnya budaya hafal Al-Qur'an maka umat Islam tidak akan susah diajak berlayar ke pulau Al-Qur'an.
\end{abstract}

Kata kunci: Pendidikan Islam; Tahfidz Qur'an; Ulama Bugis; Lanre Said

\section{Pendahuluan}

Indonesia sebagai negara yang pemeluk Islamnya terbanyak di dunia sudah barang tentu mempunyai sejarah tentang keislaman. Termasuk perkembangan islamisasi, terutama di bidang ilmu pengetahuan. Penyebaran pengaruh Islam yang berasal dari Jazirah Arab ke Asia dan benua lainnya, menimbulkan munculnya pusat-pusat agama Islam di kawasan tersebut yang berguna sebagai pusat pemerintahan dan peradaban, sekaligus sebagai pusat pendidikan sebagai sarana utama dalam berdakwah dan melakukan regenerasi dai, pendidikan, hingga ulama penuntun umat.

Para dai yang berprofesi ganda sebagai pedagang yang menjalin hubungan dengan penguasa dan pengusaha di Indonesia yang berasal dari berbagai latar belakang mulai dari Cina India, Persia, Arab, Mesir dan Turki. Adanya interaksi sosial antara pedagang muslim yang dai itu dengan masyarakat setempat inilah yang akhirnya memberi pengaruh masuknya nilai-nilai dan ajaran Islam sehingga semakin banyak yang memeluk agama Islam. 
Teori dakwah secara sistematis yang dilakukan para dai pedagang dalam penyampaian dakwahnya adalah sebagai berikut: Mula-mula para dai pedagang berdatangan ke pusat perdagangan, lalu kemudian mulai ada yang bertempat tinggal, baik sementara maupun menetap. Lambat laun tempat tinggal mereka berkembang menjadi perkampungan muslim dari negeri asing yang disebut pekojan.

Status sosial yang tinggi, memudahkan mereka mengawini pribumi baik rakyat biasa maupun anak bangsawan. Sebelum pernikahan, calon istrinya diislamkan dahulu dengan mengucapkan dua kalimat syahadat. Lalu berkembang menjadi perkampungan, masyarakat dan kerajaan Islam.

Sehingga dengan demikian, para pedagang mempunyai andil besar dalam penyebaran Islam melalui pendidikan sosial kemasyarakatan, seperti cara berdagang Islam, cara bermasyarakat, upacara pernikahan sampai pada cara bersosialisasi sehari-hari yang telah mereka praktikkan dalam kehidupan kesehariannya.

Namun, ada pula yang memang sengaja datang berdakwah tanpa bermaksud berdagang, dan sasaran utama mereka adalah para penguasa setempat. Dai semacam ini adalah biasanya utusan dari kerajaan Islam di tempat lain. Untuk kasus semacam ini dapat dilihat yang terjadi di kerajaan Gowa-Tallo atau Makassar.

Setelah Islam diterima oleh masyarakat Indonesia tanpa melalui konfrontasi fisik secara berarti, maka masalah yang muncul belakangan adalah mengajarkan para mualaf tersebut agama Islam dengan baik dan benar. Karena terbatasnya jumlah personil guruguru yang dapat mendidik umat di sebuah tempat dengan durasi waktu tertentu, menjadikan mayoritas bangsa Indonesia yang Islamnya belum maksimal. Ada yang telah turun-temurun memeluk Islam namun belum juga dapat membaca Al-Qur'an dengan betul, belum menunaikan salat wajib lima waktu dengan sempurna, bahkan rukun-rukun Islam lainnya, kecuali syahadat belum dipahami dan dilaksanakan secara benar.

Para ulama Bugis sejak dulu dikenal sebagai peletak dasar-dasar pendidikan Islam. Mereka merespons dengan baik setiap pergantian zaman, serta tetap menjadi bagian penting dalam membangun bangsa lewat dunia pendidikan dengan mencerdaskan kehidupan bangsa dan membangun masyarakat beradab.

\section{Metode Penelitian}

Pendekatan yang digunakan dalam penelitian ini adalah pendekatan kualitatif, yaitu prosedur penelitian yang mendeskripsikan perilaku orang, peristiwa atau tempat tertentu secara rinci dan mendalam (Umar, 2000). Pendekatan ini bertujuan untuk menggambarkan sesuatu yang tengah berlangsung pada saat riset dilakukan dan memeriksa sebab-sebab dari sesuatu gejala tertentu (Ahmad Kadir, 2003). Dalam hubungan ini, peneliti akan mendeskripsikan tentang pemikiran pendidikan KH. Lanre Said. Adapun sumber data ada dua yaitu, data primer dan data sekunder. Data primer 
pada penelitian pemikiran pendidikan KH. Lanre Said adalah data karya-karya orisinal KH. Lanre Said yang merupakan materi pendidikan yang ia ajarkan kepada para santrinya, juga observasi langsung ke lembaga pendidikan yang didirikan oleh KH. Lanre Said, termasuk melakukan wawancara kepada narasumber yang dipandang memiliki otoritas terkait pengetahuan tentang KH. Lanre Said berasal dari mantan santrisantrinya. Metodologi yang digunakan dalam penelitian ini adalah deskriptif kualitatif yang di dalamnya meliputi: metode kajian pustaka; metode pengamatan; metode pengamatan berpartisipasi (participant observation); metode wawancara sambil lalu; metode wawancara mendalam; dan metode mendengarkan. Dalam proses analisis data, ada tiga komponen utama yang harus dilakukan yaitu, reduksi data, sajian data, dan penarikan kesimpulan ataupun verifikasi. Tiga komponen ini terlibat dalam proses yang saling berkaitan serta menentukan hasil akhir analisis (Ahmad Kadir, 2003). Sajian data adalah suatu rakitan organisasi informasi yang memungkinkan kesimpulan penelitian dapat dilakukan. Sajian data meliputi rangkaian deskriptif yang dijalin sedemikian rupa sehingga memperlihatkan satu kesatuan yang utuh. Kesemuanya itu dirancang guna merakit informasi secara teratur supaya mudah dilihat dan dimengerti dalam bentuk yang kompak. Dari awal pengumpulan data, peneliti sudah harus memahami apa arti dari berbagai hal yang ditemukan dengan mulai melakukan pencatatan pola-pola, pernyataan-pernyataan, konfigurasi-konfigurasi yang mungkin, sebab-akibat dan berbagai preposisi. Kesimpulan-kesimpulan tersebut pada waktu awal kurang jelas, kemudian semakin meningkat secara eksplisit dan memiliki landasan yang kuat. Kesimpulan akhir tidak akan terjadi sampai proses pengumpulan data berakhir. Kesimpulan yang perlu diverifikasi dilakukan pada waktu menulis dengan melihat kembali fieldnotes yang tersedia (Abd Kadir, 2008)

\section{HASIL DAN PEMbahasan}

\section{A. Pemikiran Pendidikan Islam di Indonesia}

Diskursus tentang pemikiran pendidikan Islam di Indonesia dalam telaah historis sosiologis serta wacana dan dinamika yang berkembang di dalamnya akan kita belah menjadi dua bagian, yaitu periode sebelum Indonesia merdeka 1900-1945 dan periode setelah Indonesia merdeka, tahun 1945-sekarang. Pada pembahasan ini akan dikaji masing-masing kedua periode tersebut, termasuk dinamika yang muncul dalam hal-hal yang terkait dengan pengembangan pendidikan Islam, terutama di kalangan para pemikir, pengembang, dan pengelola pendidikan Islam dari satu periode ke periode selanjutnya di negeri ini (Hasbullah, 1999).

Setidaknya ada dua tujuan pendidikan dengan tingkat keragamannya masing-masing jika ditinjau dari secara teoritis, pertama adalah pendidikan berorientasi 
kemasyarakatan, yaitu pandangan yang menganggap pendidikan sebagai sarana utama dalam menciptakan rakyat yang baik, baik untuk sistem pemerintahan demokratis, oligarkis, maupun monarkis. Pandangan teoritis yang kedua lebih pada orientasi individu, yang lebih memfokuskan diri pada kebutuhan, daya tampung, dan minat pelajar.

Asumsi bahwa manusia adalah hewan yang bermasyarakat (social animal) dan ilmu pengetahuan pada dasarnya dibina di atas dasar-dasar kehidupan bermasyarakat, mereka yang berpandangan kemasyarakatan berpendapat bahwa pendidikan bertujuan mempersiapkan manusia yang bisa berperan dan menyesuaikan diri dalam masyarakatnya masing-masing. Berdasarkan hal ini, tujuan dan target pendidikan dengan sendirinya diambil dari dan diupayakan untuk memperkuat kepercayaan, sikap, ilmu pengetahuan, dan sejumlah keahlian yang sudah diterima dan sangat berguna bagi masyarakat. Konsekuensinya, karena kepercayaan, sikap, ilmu pengetahuan, dan keahlian yang bermanfaat dan diterima oleh sebuah masyarakat itu senantiasa berubah, mereka lalu berpendapat bahwa pendidikan dalam masyarakat tersebut harus bisa mempersiapkan peserta didiknya untuk menghadapi segala bentuk perubahan yang ada. Pendidikan Indonesia tidak akan pernah lebih baik jika generalisasi sains masih ada, apalagi jika fardu kifayah sains lebih disukai dan mengabaikan fardu 'ain sains. Kurikulum pendidikan yang dilakukan secara hierarkis dengan klasifikasi fardu 'ain dan fardu kifayah sains adalah cara untuk menjadikan Indonesia sebagai muslim yang baik dan ulama yang baik (Ardiansyah, Hafidhuddin, Mujahidin, \& Syafrin, 2017).

Mereka yang meyakini bahwa pendidikan sebagai sesuatu yang memainkan peranan penting dalam membentuk masyarakat beranggapan bahwa masyarakat jauh lebih penting dari pada individu. Ciri khas pendidikan yang berorientasi masyarakat adalah mengutamakan kebutuhan masyarakat dan menjadikan minat peserta didik sebagai prioritas kedua. Pada era modern ini, tokoh-tokoh filsafat pendidikan yang berhaluan sosialis dan komunis dengan terang-terang menekankan dimensi sosial daripada dimensi demokrasi liberal yang lebih mengutamakan individu daripada masyarakat (Husaini, 2013).

\section{Corak Pendidikan di Indonesia}

Warna pendidikan pada periode sebelum Indonesia merdeka setidaknya ada dua corak, yang pertama jenis pendidikan yang berpusat pada pondok pesantren yang didirikan dan dikelola oleh para kiai dan santri (Damanhuri, Mujahidin, \& Hafidhuddin, 2013). Kedua, corak baru yang dibawa dari kolonial Barat seperti sekolah-sekolah yang didirikan oleh pemerintah Belanda (Muljana, 2008). Ciri-ciri dari corak lama adalah (1) adanya kiai atau ulama yang hanya menguasai ilmu-ilmu agama; (2) kurang diberikan pengetahuan umum kepada peserta didik atau bahkan tidak sama sekali; (3) sikap eksklusif disebabkan sikap nonkooperasi secara total dari pihak pesantren terhadap apa saja yang beraroma Barat, dan aliran kebangunan Islam tidak leluasa untuk bisa masuk karena dihalang-halangi oleh pemerintah Belanda. Di lain pihak Belanda memiliki sistem 
pendidikan yang bertolak belakang dengan kaum pribumi seperti, hanya menonjolkan sisi intelek dan sekaligus hendak melahirkan kaum intelek semata dan umumnya bersikap negatif terhadap agama Islam (Hasbullah, 1999).

Pada corak pendidikan pesantren, tujuan utamanya adalah mengeluarkan calon lulusan yang difokuskan untuk menguasai ilmu-ilmu agama. Tradisi pondok pesantren setidaknya memiliki lima elemen dasar, yakni, pondok, masjid, pengajaran kitab-kitab Islam klasik (kitab kuning), dan kiai (Mujahidin, 2005). Menurut Martin van Bruinessen, salah satu tradisi agung di Indonesia adalah tradisi pengajaran agama Islam, misalnya di pondok pesantren, yang bertujuan untuk mentransmisikan Islam tradisional sebagaimana yang terdapat dalam kitab-kitab klasik yang ditulis berabad-abad yang lalu. Pondok pesantren tradisional sistem pengajarannya diselenggarakan di bawah kepemimpinan kiai yang dibantu oleh beberapa orang ulama atau para ustaz yang hidup bersama di tengah-tengah para santri dengan masjid atau surau sebagai pusat kegiatan keagamaan, gedung sekolah atau ruang-ruang belajar mengajar, serta pondok sebagai tempat tinggal para santri. Proses belajar mengajar dilakukan melalui struktur, metode, dan literatur tradisional, baik berupa pendidikan formal di sekolah atau madrasah dengan jenjang yang bertingkat, atau pun pemberian pengajaran dengan sistem halaqah. Ciri utama dari pengajaran tradisional adalah pemberian ajarannya yang ditekankan pada penghafalan, pemahaman, dan pengamalan atas suatu kitab tertentu (Bruinessen, 1999).

Pendidikan dalam dunia pesantren, sebagaimana yang penulis rasakan, hakikat pendidikan adalah yang mampu memahami kitab-kitab keagamaan yang sulit sekalipun, serta mampu mengajarkan ilmunya pada orang lain. Untuk itulah jenjang pendidikan dipondok pesantren dibutuhkan, termasuk pada awal-awal belajar seorang siswa harus menguasai ilmu-ilmu alat, terutama bahasa Arab dan segala instrumennya. Hakikat peserta didik atau santri adalah seorang yang sedang belajar memahami agama dan mengembangkan perasaan beragama dengan mendalam. Kurikulum adalah rencana pelajaran sebagaimana tertuang dalam kitab-kitab keagamaan produk ulama terdahulu. Evaluasi adalah penilaian kemampuan santri dalam menguasai kitab-kitab yang dipelajari untuk selanjutnya meningkat dalam mempelajari kitab yang kitab-kitab lanjutan.

Pada tahun 1909, madrasah-madrasah dengan sistem berkelas (klasikal) mulai muncul, menurut penelitian Mahmud Yunus, pendidikan Islam yang kali pertama memiliki kelas dan memakai bangku, meja, dan papan tulis adalah Madrasah Adabiyah (Adabiyah School) di Padang. Madrasah Adabiyah adalah madrasah pertama di Minangkabau, bahkan di seluruh Indonesia, yang didirikan oleh Syaikh Abdullah Ahmad pada tahun 1909. Madrasah ini hidup sampai tahun 1914, kemudian diubah menjadi HIS 
Adabiyah pada tahun 1915, yang merupakan HIS pertama di Minangkabau yang memasukkan pelajaran agama Islam dalam pengajarannya (Manti, Husaini, Mujahidin, \& Hafidhuddin, 2016; Yunus, 1996).

Munculnya sekolah-sekolah Islam yang bersepadu dengan sistem pendidikan modern juga tak terlepas dari banyaknya alumni Al-Azhar Mesir yang telah menyelesaikan pendidikannya di sana (Yunus, 1996). Mereka adalah hasil dari sistem pendidikan yang telah direformasi oleh Muhammad Abduh. Setibanya di Indonesia, mereka mengelola dan mengajar di sekolah-sekolah agama serta memasukkan mata pelajaran umum. Lembaga pendidikan yang demikian dinamai Madrasah Guru Islam atau Sekolah Menengah Islam (SMI). Di antara madrasah yang juga termasuk awal adalah Al-Jami'ah Islamiyah, di Sungayang Batusangkar, didirikan oleh Mahmud Yunus pada 20 Maret 1931; Normal Islam (Kuliah Mu'allim Islamiah), didirikan oleh Persatuan Guru-guru Agama Islam (PGAI) di Padang pada tanggal 1 April 931 dan dipimpin oleh Mahmud Yunus, dengan demikian Mahmud Yunus memimpin dua madrasah tingkat menengah dan tinggi di atas; Islamic College, didirikan oleh Persatuan Muslim Indonesia (Permi) di Padang pada tanggal 1 Mei 1931 dan dipimpin oleh Mr. Abdul Hakim. Kemudian digantikan oleh Mukhtar Yahya tahun 1935 (Yunus, 1996).

Selanjutnya berdirilah beberapa madrasah yang memasukkan pengetahuan umum dalam rencana pendidikannya, di antaranya, Training College didirikan oleh Nasruddin Thaha di Payakumbuh tahun 1934; Kulliah Muballghin/Muballighat, didirikan oleh Muhammadiyah di Padang Panjang; Kulliah Muallimat Islamiah, didirikan oleh Rgk. Rahmah Al-Yunusiah di Padang Pandang tanggal 1 Februari 1937; Kulliah Dianah, didirikan oleh Syaikh Ibrahim Musa di Parabek pada tahun 1940 dan dipimpin oleh H. Bustami A. Gani; Kulliatul Ulum, didirikan oleh Thawalib Padang Panjang dan dipimpin oleh Engku Mudo Abdul hakim; Kulliah Syariah, didirikan oleh Tarbiyah Islamiah di Padang Panjang; Nasional Islamic College, didirikan oleh alumni Islamic College di Padang; Modern Islamic College didirikan oleh St. Sulaiman dan kawan-kawan di Bukittinggi (Yunus, 1996),

Secara garis besar, dapat ditarik benang merah bahwa sebelum Indonesia merdeka terdapat berbagai corak pengembangan pendidikan Islam, yaitu, pertama, isolatiftradisional, dalam arti tidak menerima apa saja yang berbau Barat (kolonial) dan terhambatnya pengaruh pemikiran-pemikiran modern dalam Islam untuk masuk ke dalamnya, sebagaimana tampak pada pendidikan pondok pesantren tradisional yang hanya menonjolkan ilmu-ilmu agama Islam, sedangkan pengetahuan umum tidak diberikan, kecuali beberapa keterampilan seperti bertani, bertukang, beternak dan berdagang demi untuk bekal hidup seadanya, karena memang kesederhanaan menjadi ciri khas seorang penganjur dan pendidik agama (kiai). Hakikat pendidikan Islam, sebagaimana dalam tradisi pondok pesantren adalah sebagai suatu upaya untuk 
melestarikan dan mempertahankan khazanah pemikiran ulama terdahulu seperti yang telah tertuang dalam kitab-kitab muktabar. Tujuan pendidikan tak lain dan bukan kecuali untuk melahirkan para ulama sebagai pewaris para nabi, dan umara yang berjiwa ulama.

Kedua, sintesis, yakni kolaborasi antara corak lama (pondok pesantren tradisional) dan corak baru yaitu nuansa modern sebagaimana model kolonial Belanda yang berwujud sekolah formal sebagaimana madrasah. Dalam realitasnya, corak pemikiran sintesis ini mengandung beberapa variasi pola pendidikan Islam, seperti pola pendidikan madrasah mengikuti format pendidikan Barat terutama sistem pengajarannya secara klasikal, tetapi sistem pendidikan tetap lebih menonjolkan ilmu-ilmu agama Islam, sebagaimana dikembangkan pada Madrasah Sumatera Thawalib, Madrasah Tebuireng asuhan KH. Hasyim Asy'ari, atau Madrasah Arabiyah Islamiyah (MAI) Sengkang dibawa Anregurutta Haji Muhammad As'ad; pola pendidikan madrasah yang mengutamakan pelajaran agama, tetapi mata pelajaran umum secara terbatas juga diberikan seperti yang dikembangkan oleh Madrasah Diniyah Zaenuddin Labay el-Yunusi dan Madrasah Salafiyah Tebuireng pimpinan KH. Ilyas; pola pendidikan madrasah yang menggabungkan secara lebih seimbang antara muatan keagamaan dan non-keagamaan, seperti yang dikembangkan oleh Muhammadiyah, dan Pondok Modern Gontor Ponorogo, dan pola pendidikan sekolah yang mengikuti pola pemerintah Hindia Belanda dengan ditambah beberapa mata pelajaran agama, sebagaimana yang dikembangkan oleh Madrasah Adabiyah dan sekolah-sekolah yang dikelola oleh Muhammadiyah (Mahlani, 2013).

\section{Pendidikan Islam di Sulawesi Selatan}

Di Sulawesi Selatan, secara umum para raja-raja memberi keleluasaan kepada para dai dan ulama sekaligus pendidik untuk mengembangkan syiar agama Islam dan pendidikan. Raja Gowa yang bergelar Imangimangi Daeng Matuju Karaeng Bontonompo Sultan Muhammad Tahir Muhibuddin (1936 - 1946) menggagas pembukaan Madrasah Islamiyah, bertempat di Jongaya, Gowa (Palimai, 2010).

Pengajaran agama Islam yang diberikan berdasarkan mazhab Syafii. Pimpinan Madrasah dipegang oleh Asy Syekh Abdullah bin Shadaqah Dahlan, penganjur mazhab Imam Syafii yang taat. Madrasah ini dibuka, setelah beberapa bulan Sultan Muhammad Tahir naik takhta di Gowa pada tahun 1936. Para murid-murid madrasah ini berasal dari daerah Takalar, Jeneponto, dan dari daerah Gowa sendiri. Ketika pecah perang dunia ke II madrasah ini terpaksa ditutup, perang memang selalu membawa petaka (Palimai, 2010).

Sebelum itu, di daerah Campalagian Mandar, menurut catatan, pendidikan dengan sistem tradisional telah bermula dari tahun 1913 di bawah asuhan H. Maddeppungeng 
yang pernah berguru di Mekah Saudi Arabia. Tempat ini menjadi pencetak kader-kader mubalig Islam di Sulawesi Selatan pada awal abad ke XX. Tempat pendidikan ini tidak membatasi usia para pelajarnya (Pawiloy, 1987). Di kerajaan Wajo ketika diperintah oleh La Mannang Toapamadeng Puangna Raden Galla, Arung Matoa ke-40 yang berkuasa pada tahun 1821-1825, beliau melakukan berbagai usaha dalam bidang pendidikan dan agama, seperti: memperluas dan menyempurnakan Masjid Jami' Tosora; mendatangkan ulama dari Madinah, (biasa disebut oleh orang Wajo dengan Syekh Madinah); mengeluarkan perintah pada raja-raja bawahannya agar masjid yang ada dipelihara dan diperbaiki, dan yang belum memiliki masjid agar segera membangun supaya rakyat dapat salat secara berjamaah; pohon-pohon yang dikeramatkan agar ditebang; perempuan yang keluar rumah agar menggunakan tutup kepala dan kain sarung (baca: kerudung); dan dari segi pelaksanaan hukum, pemerintah memotong tangan bagi pencuri atas anjuran Syekh Madinah. Ketika La Oddang Datu Larompong, Arung Matoa Wajo ke-47, memerintah Wajo dari tahun 1926-1933. Beliau memiliki pengetahuan agama yang dalam, karena sejak kecil dididik oleh orang tuanya dalam masalah keagamaan. Beliau disifatkan sering bergaul dengan para Ulama seperti, Haji Makkatu, seorang Ulama yang sangat tegas dalam memberantas segala kemungkaran dan merintis pengajian yang bersifat klasikal di Tosora, juga beliau dekat dengan Al-Bugisi, seorang Ulama Bugis yang lahir di Mekkah, ke Wajo pada tahun 1928 yang sangat berjasa dalam mengembangkan pendidikan Islam di Sulawesi Selatan dengan mencetak para ulama berkaliber nasional dan internasional, dia juga sebagai pelopor pemurnian ajaran agama Islam dan pembaruan sistem pendidikan Islam dengan Madrasah Arabiyah Islamiyah (MAI) yang berpusat di Sengkang (Palimai, 2010).

Demikian pula di Kerajaan Bone, berkat bantuan Andi Mappanyukki alias Petta Mangkau Bone, pada tahun 1929 didirikan sebuah madrasah yang diberi nama "Madrasah Amirah" di Watampone. Pimpinannya ialah Abdul Aziz Asy Syimie berasal dari Mesir, pada tahun 1935 pimpinan madrasah beralih ke tangan Ustaz Abdul Hamid al Misyrie dan selanjutnya digantikan oleh Ustaz Mahmud al Jawad bekas Mufti Madinah al Munawarah yang sebelumnya pernah mengajar di Palopo, pada perkembangan selanjutnya tahun 1940 dibangunlah asrama para pelajar sebagai tempat tinggal dan juga dibangunkan gedung belajar yang teratur. Para pengasuh madrasah ini adalah para Ulama dari Bone sendiri yang pernah mukim dan belajar di Makkah dan Mesir (Palimai, 2010).

Selanjutnya pada tahun 1932 atas inisiatif Raja Bone Andi Mappanyukki diadakan "Pertemuan Ulama se-Celebes Selatan" di Watampone, ibukota kerajaan Bone. Musyawarah tersebut dihadiri oleh dua puluh enam Ulama terkemuka dari seluruh Sulawesi Selatan termasuk Gurutta H. M. As'ad, dan membicarakan cara-cara pengelolaan pendidikan Islam bagi masyarakat umum (Palimai, 2010) 


\section{B. Pendidikan Kader Ulama Bugis}

Karena kajian ini berhubungan dengan ulama Bugis, maka akan lebih baik jika membahas masalah kedudukan ulama Bugis yang sejatinya merupakan hasil pendidikan yang sangat sistematis dan terarah. Masyarakat Bugis menyebut ulama dengan panggilan anregurutta dan gurutta, dan pada saat seorang ulama sudah matang atau mencapai tingkat keahlian dalam bidang keagamaan dipandang tinggi serta berada pada posisi layak menjadi panutan disebabkan oleh perilakunya yang saleh, maka ia akan disebut sebagai seorang panrita (Abd Kadir, 2008).

\section{Epistemologi}

Ditilik dari segi bahasa panrita berasal dari kata ita yang berarti orang yang melihat, umum pula ditulis topanrita tambahan to adalah bahasa Bugis yang bermakna orang. Dalam perkembangannya, kata panrita bisa berarti keahlian teknis, seperti tercermin dari ungkapan panrita lopi (ahli pembuat perahu), panrita bola (ahli dalam membuat rumah), namun dalam pengertian lebih spesifik setelah terjadi islamisasi secara masif dan massal, termasuk merambah pada istilah bahasa, dan mengubah makna inti beberapa kata kunci termasuk panrita yang sebelumnya secara istilah adalah orang yang memiliki kemampuan khusus secara fisik dan metafisik.

Setelah era islamisasi, panrita berubah arti menjadi ulama, sehingga dalam masyarakat Bugis panrita loppo berarti ulama besar, atau pendeta dalam istilah agama Kristen (Ide, 1977). Dari sinilah awal mulanya seorang pakar Bugis, Cristian Pelras yakin bahwa kata panrita diambil dari bahasa Sanskerta pandita yang berarti 'pendeta atau pertapa.' Dalam pengertian Pelras, panrita adalah 'orang yang menguasai seluk beluk agama, bijaksana, saleh dan jujur (Christian, 2006)' Makna topanrita yang lebih luas diberikan oleh Mochtar Pabottingi, seorang cendekiawan asal Sulawesi Selatan. Menurutnya, panrita adalah orang yang bersaksi, melihat dan menyimak atas suatu keadaan dan menyatakan keadaan sebenarnya. Di sini, panrita bukan saja berperan sebagai pengamat yang objektif atas keadaan di sekitarnya, tapi juga memberi penilaian, kritik dan pertimbangan atas suatu keadaan. Dengan makna ini, tidak berlebihan jika topanrita diidentikkan dengan konsep cendekiawan (intellectual) dalam terminologi modern. Lepas dari beragam pengertian di atas, topanrita juga merupakan salah satu dari empat kualitas ideal manusia Bugis, di luar kebangsawanan (arung), yang disebut dalam Lontara sebagai "sulapa' eppa"' (segi empat). Keempat kualitas atau sifat tersebut merupakan modal yang harus dimiliki setiap pemimpin yang baik. Selain panrita (saleh), tiga sifat yang dimaksud adalah warani (berani), macca (cerdas) dan sugi (kaya), sebelum Islam datang, setelah hirarki golongan kaya, ada dua lagi lapisan masyarakat yang tersisa, maradeka dengan ata atau golongan merdeka dan hamba (Christian, 2006). 
Menurut Mattulada, keempat sosok ideal ini, yang dia sebut sebagai 'golongan fungsional', termasuk lapisan elite kedua dalam pelapisan masyarakat Bugis-Makassar periode Lontara (Mattudala, n.d.). Lapisan elite pertama adalah Arung yang terdiri atas anakarung, yaitu raja dengan lingkungan kerabat keluarga bangsawan yang menduduki jabatan-jabatan kepemimpinan politik pemerintahan secara turun-temurun, baik di pusat kerajaan maupun di daerah-daerah bawahannya. Anakarung menduduki status sosial tertinggi dalam masyarakat karena, secara genealogis, leluhur mereka dipercaya bersambung hingga ke sosok tomanurung. Konsep tomanurung (orang yang turun dari langit) ini diadopsi oleh kerajaan-kerajaan utama di Sulawesi Selatan, khususnya Luwu, Gowa, Bone dan Soppeng. Untuk menjelaskan asal-usul kemunculannya seorang raja dan legitimasi tradisionalnya untuk menjadi pemimpin dalam masyarakatnya. Konsep ini sangat menentukan dalam proses pelapisan struktur sosial-politik dalam wilayah berbagai kerajaan Bugis-Makassar khususnya, dan wilayah Austronesia pada umumnya. Dalam konsep tomanurung, (Mattudala, n.d.) kemunculan atau kehadiran seorang raja pertama digambarkan secara mitologis sebagai berasal dari langit dan merupakan manusia setengah dewa. Mitos ini memberikan kepadanya kewibawaan yang tinggi sehingga mendapatkan kepatuhan dan penghormatan dari rakyatnya (Mattudala, n.d.).

\section{Peranan dan Kedudukan Panrita}

Terkait peran dan kedudukan panrita sebelum Islam masuk secara resmi di Sulawesi Selatan dapat dilacak dari berbagai kerajaan, misalnya kerajaan Wajo pada abad ke-15, hiduplah salah satu panrita bernama La Tiringeng To Taba' (Abad ke-15 M) tak dapat dipisahkan dari perjanjian awal antara rakyat dan raja Wajo yang berhasil merumuskan prinsip-prinsip utama ketatanegaraan (konstitusi) kerajaan Wajo di abad ke-15. La Tiringeng mewujudkan diri sebagai sosok topanrita Bugis. Dalam berbagai Lontara Wajo, dia digambarkan sebagai seorang cendekiawan dan negarawan yang tidak saja bijaksana, cerdas dan mencintai rakyatnya, tetapi juga seorang ahli dan penegak hukum yang tegas, jujur dan tidak terbius oleh kekuasaan dan kekayaan (Patunru, 1965). Tidak aneh jika petuah-petuahnya lebih dari enam abad silam, menurut banyak pengamat budaya, masih relevan untuk ditelaah sebagai sumber inspirasi, landasan etika dan pedoman dalam menata kehidupan sosial, hukum, politik dan pemerintahan kontemporer, baik di tingkat lokal, regional maupun nasional (Halim \& Sesember, 2012). Salah satu pesan La Tiringeng yang kerap kali dirujuk untuk menunjukkan aktualitas pesan itu dengan kondisi kontemporer adalah, "Napoallebirengngi to Wajoè, maradèkaè, na malempu, na mapaccing ri gau' salaè, marèso mappalaong, na maparekki ri warang-paranna". Orang Wajo mulia karena mereka memiliki kebebasan, kejujuran, kesucian dari perilaku buruk, kerajinan bekerja, dan memelihara harta benda (Noorduyn, 2000).

Ada pun panggilan anregurutta hanya akan disematkan kepada seorang ahli agama namun tidak untuk yang ahli dalam ilmu pengetahuan lainnya, ilmu agama dimaksud adalah terminologi ilmu-ilmu fardu 'ain dalam pandangan Al-Gazali dan ilmu naql 
menurut Ibn Khaldun. Karena itu, orang Bugis memahami ulama dengan pengertian khusus (Al-Jauziyah, 2012; Khaldun, 2010; Munawwir, 2006). Secara hierarkis, ulama Bugis juga bertingkat-tingkat, yang tertinggi adalah panrita, lalu menyusul anregurutta, kemudian gurutta, dan para ustaz, hanya saja, seorang panrita disebut juga anregurutta dan gurutta kedua gelar terakhir ini kerap berganti-ganti.

Namun demikian, istilah kiai sebagaimana dipergunakan oleh masyarakat Jawa juga dipakai untuk menyebut golongan ulama, atau pimpinan pesantren dan mengajar kitabkitab klasik (turâts) kepada para santrinya, dalam penelitian ini kata 'kiai' juga digunakan untuk menunjukkan kata ganti ulama, anregurutta, dan gururtta (Dhofier, 1994). Hanya saja, penggunaan istilah kiai dalam masyarakat Bugis bersifat umum untuk semua ahli agama, sementara istilah anregurutta selain menunjukkan kompetensi yang dimiliki juga merujuk pada perilaku kesehariannya (ampe-ampe madeceng) yang melambangkan dan menunjukkan kharisma dan kewibawaannya di tengah masyarakat, karena itulah, menurut Ahmad, anregurutta atau gurutta memang lebih spesifik untuk ulama Bugis. Dilihat dari sudut kompetensi, memang ulama Bugis, setidaknya merujuk pada tiga kompetensi dasar, meliputi, penguasaan ilmu agama, pengamalan agama, dan akhlak kepribadian (Abd Kadir, 2008).

Tempat reproduksi ulama dalam masyarakat Bugis tidak berbeda dengan di Jawa, yaitu berasal dan berawal dari pesantren lalu diaplikasikan ilmunya, dan dimatangkan di tengah masyarakat. Pengetahuan yang selama ini bersifat teoritis di pesantren akan diuji di tengah masyarakat. Proses pematangan yang melibatkan ketiga komponen di atas akan menjadi penentu eksistensi seorang ulama Bugis. Posisi pesantren yang terbuka secara umum memungkinkan reproduksi ulama tetap terjaga, padahal awal-awal kedatangan Islam, umumnya ulama yang kelak akan menjadi panrita lebih didominasi kaum anakarung (bangsawan). Seiring berlalunya waktu, pondok pesantren dan madrasah membuka diri untuk semua kalangan yang ingin menjadi ulama menjadikan kaderisasi ulama berjalan secara berkesinambungan, dapat diakses oleh masyarakat luas (Abd Kadir, 2008).

Jika di Jawa pola-pola kaderisasi ulama umumnya melibatkan jaringan antargenealogi kekerabatan. Unsur keturunan dalam kalangan pesantren tradisional di Jawa memegang peranan penting dalam kaderisasi kiai. Seorang kiai tradisional mungkin anak dari kiai, atau kalau ayahnya bukan kiai, maka salah seorang familinya adalah kiai, atau memang kakeknya seorang kiai, begitulah seterusnya. Ini pula yang membedakan dengan ulama Bugis yang lebih cenderung bergerak di luar pola hubungan genealogi kekerabatan sehingga sulit menemukan adanya anak ulama melakukan hubungan pernikahan dengan ulama lainnya. Pola koneksi atas dasar genealogi keilmuan lebih diutamakan daripada 
kekerabatan. Ulama Bugis mereproduksi santri menjadi ulama lebih dari sekadar mereproduksi anak keturunan menjadi ulama.

Pola regenerasi ulama khas Bugis juga dijumpai dalam penelitian ini yang mengungkap konsep kaderisasi ulama yang pernah diterapkan oleh Al-Bugisi yang merintis dan memimpin Madrasah Arabiah Islamiyah (MAI) yang berlokasi di Sengkang, lembaga pendidikan yang bertahan hingga hari ini telah terbukti menjadi alat reproduksi ulama Bugis. Para generasi pelanjut adalah terdiri dari para santri pilihan yang dianggap cakap menata dan mengatur lembaga serta memiliki keilmuan yang memadai lalu disempurnakan dengan pengamalan yang konsisten serta ketinggian adab yang dikenal dengan ampe-ampe madeceng (akhlak mulia).

\section{PERAN DAN PEMIKIRAN K.H. LANRE SAID \\ 1. Tujuan Pendidikan Lanre Said}

Lanre Said jika ditelusuri secara mendalam dapat dipahami tujuan pendidikan yang ia inginkan. Dalam berbagai kesempatan, sebagaimana yang dituturkan oleh muridnya, bahwa tujuan utama pendidikan yang ia inginkan adalah untuk mencetak generasi pelanjut yang mampu melahirkan manusia saleh, beradab, tangguh dalam berjuang, memiliki pemahaman keagamaan yang berdasarkan dengan apa yang telah ajarkan oleh Nabi Muhammad dan telah dilalui dan dipraktikkan bersama para sahabat-sahabatnya, serta para tabiin dan pengikut tabiin.

Untuk mencapai target yang berat itu, maka para santri harus melalui proses dan perjalanan yang cukup panjang. Dimulai dengan penguasaan terhadap al-Qur'an lewat hafalan 30 juz, dipertajam dengan kemampuan bacaan yang baik dan benar sesuai kaidah-kaidah tajwid, pemahaman tentang al-Qur'an itu sendiri dengan terlebih dahulu mengajarkan dan memahamkan ilmu-ilmu alat yang berhubungan dengan al-Qur'an, seperti pelajaran Ulumul-Qur'an yang di dalamnya berbagai jenis ilmu, misalnya, nasikh wal mansukh, asbabun-nuzul, al-qira'ah assab'ah dan lain-lain.

Penguasaan ilmu dua belas juga kerap ia tekankan, agar dapat memahami al-Qur'an dan ilmu-ilmu yang berhubungan dengan kitab suci. Yang dimaksud dengan ilmu dua belas nahwu, sharaf, balaghah yang meliputi, bayan, badi', dan ma'ani. Tafsir, ulumultafsir, hadis, ulumul-hadits, fiqih, dan ushulul fiqih, dan mantik. Dengan penguasaan terhadap al-Qur'an dan perangkat-perangkatnya, maka secara perlahan seorang santri akan dapat mencapai gelar ulama, karena dibekali dengan hafalan Al-Quran. Tapi, selain kapasitas intelektual bagi Lanre Said juga mencontohkan langsung bagaimana seorang pimpinan yang hidup dengan sederhana dan bersahaja. Hidup apa adanya, dan tidak banyak menuntut. Karena baginya, hanya dengan hidup sederhana seorang ulama akan bisa berjuang dengan sungguh-sungguh. 
Selain itu, Lanre Said, dalam berbagai ceramahnya selalu menyatakan bahwa tujuan didirikannya lembaga pendidikan Majelisul Qurra Wal Huffadh adalah untuk berlayar ke sebuah pulau yaitu pulau al-Qur'an dan hadis sahih yang telah dicontohkan oleh Nabi dan Para sahabat-sahabatnya, serta para tabiin dan pengikut para tabiin. Kalau para santri dan pelanjutnya kemudian tidak memahami tujuan pondok yang ia ibaratkan sebagai kapal itu, maka susah untuk mencapai tujuan mulia itu.

Untuk itu, sejak awal Lanre Said telah menanamkan ilmu, ibadah, dan amal yang benar kepada segenap santrinya. Perkara-perkara bidah akidah dan ibadah telah ia tuangkan dengan baik melalui tulisan-tulisannya dalam kitab Adz-Dzikra. Dengan ilmu, ibadah, dan amal yang benar diharapkan dapat benar-benar melahirkan alumni yang siap untuk mengabdi pada umat.

Kecuali itu, Lanre Said juga menekankan bahwa saat ini adalah masa yang tersulit bagi umat Islam, terutama yang berada di pedalaman. Ini terjadi karena para ulama, cendekiawan, penyuluh agama berlomba-lomba masuk ke kota untuk mengejar kemewahan dan hidup senang. Di saat yang sama kegelapan menyelimuti orang-orang yang berada di pedalaman. Ia menulis bahwa akan datang suatu masa, di mana para ulama berlomba-lomba masuk kota mengejar kemewahan, dan pada saat yang sama para pendeta masuk kampung untuk menyesatkan umat.

Dari sini dapat dikatakan bahwa tujuan pendidikan menurut Lanre Said adalah untuk mencetak manusia yang beriman, berilmu, beramal saleh, saling menasihati dalam kebenaran, dan kesabaran. Inilah hakikat tujuan manusia diciptakan sebagaimana tujuan pendidikan yang ideal dan selaras dengan firman Allah dalam Surat Al-Ashr, ayat 1-3.

\section{Lembaga Pendidikan Lanre Said}

Begitu Lanre Said pulang dari rantau, dengan persiapan yang matang, ia langsung mendirikan lembaga pendidikan dalam bentuk halaqah dengan fasilitas apa adanya. Santri dan kiai menyatu dalam satu atap. Dengan rumah panggung beratap daun rumbia menjadi saksi awal mula berdirinya lembaga pendidikan Majlisul Qurra' Wal Huffadz atau MQWH, dimulai pada jam 07.00 Tanggal 7 Agustus 1975 berlokasi di kampung Tuju-tuju dan dimulai dengan 7 jumlah santri, langsung di pimpin oleh Lanre Said. Dengan fasilitas yang serba minim ini, tidak menyurutkan sama sekali semangat Lanre Said untuk maju ke depan mengejar cita-citanya yang sangat mulia.

Secara logika untuk saat itu memang hampir tidak ada yang bakal percaya kalau MQWH bisa menjelma menjadi pondok pesantren seperti sekarang (Darul Huffadh), betapa tidak, tempat belajar saja pada awal mulanya hanya belajar di bawah kolong rumah kiai yang berukuran 32 Meter persegi, materi pelajarannya pun sangat sederhana, bahkan jumlah santrinya yang sama dengan jumlah hari dalam seminggu ini lebih banyak bermandi lumpur di empang ketimbang menimba ilmu di kelas. 
Rutinitas harian para santri lebih banyak tersita dipakai untuk membangun empang agar dapat dijadikan tambak udang dan ikan demi kepentingan jangka panjang, agar kelak pondok tidak terlalu susah memikirkan masalah lauk-pauk dan sebisa mungkin agar bisa menjadikan tambak di atas sebagai sumber usaha yang dikelola oleh pondok untuk kepentingan para santri-santrinya.

Saat itu, lokasi yang akan dijadikan tambak masih berupa hutan bakau dan semakbelukar, jadi praktis, Lanre Said beserta para santrinya selama lima tahun bermula dari berdirinya MQWH pada tahun 1975-1980 hampir tidak pernah absen ke empang, bahkan tidak jarang ketika para santrinya sedang menghafal Al-Qur'an di sore hari beliau sendirian turun ke empang untuk melihat keadaan, jika ada yang bocor maka langsung ditambal agar bocornya tidak bertambah besar, dan beliau baru meninggalkan empang jika menjelang waktu Magrib.

Nominal santrinya hanya tujuh orang anak-anak yang ke semunya lulusan Sekolah Dasar, mereka juga hanya berasal dari keluarga pimpinan dan istrinya yang hanya berasal dari dua daerah Tuju-tuju dan Sumbawa.

Menurut Ilham Kadir, yang sekarang menetap di Daerah Batam Kepulauan Riau, bahwa pada dasarnya ada 8 kandidat santri yang akan diresmikan oleh Lanre Said, tetapi karena para calon santri di atas harus melewati ujian berupa harus menghafal satu juz dalam jangka masa satu bulan dan salah satu di antara para calon santri tersebut harus tereliminasi yaitu Mustaqim Yahya atau saudara dari dua santri perdana, Andi Lukman Yahya dan Andi Sudirman Yahya yang mana mereka ini adalah putra Andi Yahya, yang merupakan keluarga terdekat Lanre Said dan juga pendamping setia beliau dikala duka maupun suka, semenjak di DI/TII hingga Lanre Said lebih dulu pulang ke rahmatullah.

Jumlah santri ini bertahan hingga tahun 1979, jadi selama empat tahun pertama berdirinya pondok ini hanya memiliki tujuh santri yang selalu setia taat dan patuh pada pimpinan, mereka semua ini begitu gigih bekerja demi kemaslahatan pondok, walaupun demikian mereka juga tak hilang identitasnya sebagai santri, setiap hari dan malam mereka tetap belajar dan menambah hafalan, jika mereka tidak dapat memenuhi ketentuan target hafalan yang harus dicapai dalam sehari sebanyak satu halaman, maka mereka juga dihukum dengan cara harus menghafal al Qur'an di rumah pimpinan dari Jam 07.00 pagi hingga 12.00 siang.

Pada dasarnya sebelum Lanre Said secara formal membuka lembaga pendidikan pondok pesantren, dalam artian para santri harus tinggal bersama dengan kiai dan belajar, bekerja, serta beramal sesuai dengan ketentuan yang belaku di dalam pondok, sebenarnya Ustazah Siti Nur Hasanah atau Petta Cinnong Istri Lanre Said sudah eksis mengajar ilmu-ilmu agama fardu 'ain dan mengaji, baik untuk pemula maupun sudah lanjutan untuk masyarakat Tuju-tuju. 
Pelajaran untuk para pemula seperti biasanya belajar mengaji ala orang Bugis Bone, belajar membaca huruf hijaiah dengan menyebut, alefu ri ase'na a; alefu ri awana i; alefu dapenna $\mathrm{u}$; A, I, U, dan ada pun yang sudah bisa membaca dengan baik sesuai dengan hukum-hukum tajwid dan makhraj-nya, maka mereka akan diajar tarannum atau mallagu karena memang Petta Cinnong memiliki suara yang indah dan bacaan yang bagus ditambah dengan penguasaannya terhadap berbagai macam jenis Qira'ah. Jadi dengan sendirinya orang-orang di Tuju-tuju atau yang berasal dari kampung sebelah berduyunduyun datang ke rumah Petta Cinnong untuk belajar Tarannum.

Dikala MQWH sudah berdiri, Petta Cinnong tetap saja mengajar pada siapa saja yang ingin belajar baca tulis al Qur'an, cuma saja karena santri sudah ada, jadi secara langsung fokus utama istri pimpinan ini terkuras hampir seluruh waktunya untuk mengurus para santri ini, mulai dari memasak, mengarahkan, mendidik, mengajar, dan sebagainya. Ditambah lagi ke semua jumlah santri ini bermukim bersama Petta Cinnong, sedangkan istri yang satunya Petta Paccing belum dijadikan tempat tinggal para santri, mungkin karena pertimbangan jumlah putra-putri pimpinan yang lahir dari rahim Petta Paccing jauh lebih banyak, jadi waktunya secara langsung banyak tersita untuk mengurus anak sendiri, di samping karena memang Petta Paccing hanya ibu rumah tangga saja dalam artian tidak terlibat dalam hal belajar mengajar sebagaimana Petta Cinnong.

Pada konsep awal berdirinya pondok ini memiliki nama Darul Ulum yang telah ditetapkan oleh Lare Said saat mengadakan pertemuan keluarga di Surabaya, saat itu di depan para keluarganya beliau sudah bulat tekadnya kembali ke Sulawesi untuk mendirikan lembaga pendidikan yang berbentuk pondok pesantren dan saat itu memilih nama Darul Ulum sebagai nama pondok pesantren yang akan segera dibuka di Sulawesi Selatan tepatnya di Daerah Tuju-tuju.

Setelah kembali ke Tuju-tuju, ternyata rencana tidak selamanya berjalan dengan sesuai yang diharapkan, betapa tidak, masa lalunya sebagai Ketua Mahkamah Agung dimasa DI/TII membuat Lanre Said tetap mendapat pengawasan yang khusus di zaman itu, mulai dari pihak birokrasi seperti Lurah, Camat, Hingga Bupati atau pihak keamanan baik itu, polisi di bawah Kapolsek atau tentara di bawah Koramil, mereka tidak hentihentinya mencurigai segala sepak terjang sang Ustaz ini.

Dengan berbagai pertimbangan, setelah tiba di Tuju-tuju dan mulai merintis lembaga pendidikan yang bernuansa pondok ini, maka beliau menamakan tempat pendidikannya ini sebagai Majelis al Qurra' wal Huffadh, Majelis jika diartikan menurut etimologi atau bahasa adalah berarti tempat duduk, namun bila diartikan menurut terminologi atau istilah maka kata ini memiliki makna yang sangat beragam, mulai dari yang politis hingga yang sangat umum di telinga masyarakat, yang politis misalnya kata "Majelis" dapat diartikan sebagai dewan atau rapat yang mengembang tugas-tugas kenegaraan yang 
tertentu dan terbatas, sedangkan yang umum biasa diketahui oleh masyarakat kita adalah suatu golongan atau kelompok terkoordinasi yang rutin mengadakan pertemuan keagamaan.

Majelis al Qurra' wal Huffadh dapat diartikan dengan makna yang sederhana adalah satu tempat untuk membaca, mempelajari, dan menghafal isi al Qur'an. Dan pada tanggal 11 November 1992 adalah perubahan nama dari Majelis al Qurra' wal Huffadh menjadi Darul al Qurra' wal Huffadh, yang pada saat itu dikonsep langsung oleh Muttaqien Said di Bantu dengan para guru-guru. Satu hal yang dapat kita ambil pelajaran dari sini adalah tingginya toleransi Lanre Said dalam menghadapi bentuk-bentuk yang bersifat teknis atau istilah tanpa mengubah substansi atau isi itu sendiri.

Pada bulan Agustus 1989, merupakan babak baru dalam fase perkembangan MQWH, ini terjadi karena adanya eksodus besar-besaran alumni PM Gontor ke pondok ini, bahkan bisa dikatakan mungkin inilah pondok pesantren satu-satunya di Indonesia yang jumlah gurunya hampir separuh dari total jumlah santri secara keseluruhan pada periode 1989-1994. Para alumni PM Gontor ini menjadikan MQWH sebagai pilihan favorit untuk mengabdi, ataupun menjadikan tempat transit sebelum masuk ke bangku kuliah baik dalam maupun luar negeri ataupun bagi mereka yang ingin langsung mengabdi ke masyarakat. hal yang paling memikat hati mereka adalah dapat mengafal Al-Qur'an dengan durasi waktu yang cukup singkat, bahkan ada yang dapat khatam hanya dalam jangka masa 60 hari sambil berguru dengan Lanre Said, selain itu mereka dapat mengamalkan ilmu yang telah didapatkan di PM Gontor.

Mereka inilah para agen of change di MQWH, yang sebelumnya lembaga pendidikan ini masih mengadopsi sistem halaqah, namun semua berubah dalam jangka masa yang singkat kepada sistem modern sebagaimana PM Gontor sendiri setelah para alumninya datang ke MQWH.

Keahlian Lanre Said dalam mengatur para alumni PM Gontor ini juga harus diacungi jempol, mereka merasa diberi kebebasan sepenuhnya untuk berekspresi dalam berkarya, sama sekali tidak ada tekanan, selama untuk kebaikan dan kemajuan pondok tidak ada masalah, yang ditangani langsung oleh Lanre Said hanyalah persoalan ibadah inti saja. Adapun pengajaran dan sebagainya semua bebas ala Gontor.

Para alumni PM Gontor yang datang ke MQWH pada periode 1989-1994, mereka adalah mayoritas alumni 1989-1993, pada tahun-tahun ini para tenaga pengajar murni monopoli alumni Gontor, namun pada tahun 1994 sudah mulai juga berdatangan dari pondok alumni atau cabang Gontor, seperti Darul Arafah dan Darul Hikmah Medan Sumatera Utara, Darul Muttaqin dan Darunnajah, Bogor Jabar, dan beberapa pondok pesantren yang mengadopsi sistem KMI.

\section{KESIMPULAN}


Pemikiran pendidikan Islam sejatinya telah melahirkan gagasan dan aplikasi dalam regenerasi ulama, tidak terkecuali ulama Bugis. Maka, tugas kita hari ini adalah menjadi mata rantai ulama dan intelektual yang telah melahirkan gagasan dan gerakan pendidikan lewat berbagai macam wadah. Baik melalui lembaga, yayasan, maupun organisasi massa bahkan kementerian agama dengan tujuan melestarikan pendidikan Islam.

Pemikiran pendidikan terus berkembang untuk merespons masalah-masalah internal dan eksternal. Dari dalam para tokoh pendidikan berusaha mengembangkan pendidikan Islam dengan berbagai dinamika yang ada, menguatkan fondasi-fondasi peserta didik, khususnya terkait materi pengembangan akidah dan syariat agar mereka tetap kokoh memegang teguh keyakinan. Dari luar, berusaha beradaptasi dengan baik, menahan gempuran globalisasi, menyaring setiap sistem yang ada, lalu menyerap dan menerapkan jika dianggap perlu.

Ulama Bugis telah membuktikan bahwa mereka tetap eksis dengan perubahan zaman yang begitu cepat. Merespons dengan baik setiap pergantian zaman, tetap menjadi bagian penting dalam membangun bangsa lewat dunia pendidikan dengan mencerdaskan kehidupan bangsa, membangun masyarakat beradab. Itulah di antara inti dari tujuan pemikiran pendidikan Islam dari zaman ke zaman.

Di antara ulama terkemuka Bugis adalah Lanre Said. Beliau telah meletakkan dasardasar pemikiran pendidikan Islam di masyarakat Bugis, terutama pendidikan Tahfidzul Qur'an. Tujuan pendidikan tahfizhul qur'an bagi KH Lanre Said adalah untuk memasyarakatkan Al-Qur'an. Dengan hidupnya budaya hafal Al-Qur'an maka umat Islam tidak akan susah diajak berlayar ke pulau Al-Qur'an. Yang dimaksud Lanre Said dengan pulau Al-Qur'an adalah mewujudkan tatanan masyarakat yang hidup dengan Al-Qur'an. Masyarakat qur'ani adalah mereka yang menjadikan kitab suci sebagai ukuran benar salahnya sebuah tindakan. Pulau Al-Qur'an adalah negara yang merujuk pada Al-Qur'an dalam segala bentuk kehidupannya. Inilah tujuan tertinggi yang dikehendaki oleh Lanre Said. Wallahu A'lam!

\section{DAFTAR PUSTAKA}

Al-Jauziyah, I. al-Q. (2012). Fawâ'id al-Fâwâa'id. (Muhtadi \& A. Risdianto, Penerj.). Jakarta: Darus Sunnah Press.

Ardiansyah, M., Hafidhuddin, D., Mujahidin, E., \& Syafrin, N. (2017). The Concept of Adâb by Syed Muhammad Naquib al-Attas and Its Relevance to Education in Indonesia. International Journal of Islamic Education Ta'dibuna, 1(1), 53-64.

Bruinessen, M. van. (1999). Rakyat Kecil, Islam, dan Politik. Yogyakarta: Yayasan Bentang Budaya.

Christian, P. (2006). The Bugis. (H. dan N. S. diterjemahkan denganoleh Abdul Rahman Abu, Penerj.). Jakarta: Nalar dan Forum. 
Damanhuri, A., Mujahidin, E., \& Hafidhuddin, D. (2013). Inovasi pengelolaan pesantren dalam menghadapi persaingan di era globalisasi. Jurnal Ta'dibuna, 2(1), 17-37.

Dhofier, Z. (1994). Tradisi Pesantren: Studi tentang Pandangan Hidup Kiai. Jakarta: LP3ES.

Halim, W. H., \& Sesember. (2012). Topanrita dan Anregurutta dalam Masyarakat Bugis Abad XX. Jurnal Al- Ulum, 12(2).

Hasbullah. (1999). Sejarah Pendidikan Islam Indonesia. Jakarta: Raja Graindo Perkasa.

Husaini, A. (2013). Fiilsafat Ilmu Perspective Barat dan Islam. Jakarta: Gema Insani Press.

Ide, S. M. (1977). Kamus Bahasa Bugis-Indonesia. Jakarta: Departemen Pendidikan dan Kebudayaan RI.

Kadir, A. (2003). Metodologi Penelitian Kualitatif. In Indobis (Vol. 1, hal. 104-105). Makassar.

Kadir, A. (2008). Ulama Bugis. Makassar: Balai Penelitian dan Pengembangan Agama.

Khaldun, I. (2010). Muqaddiman Ibn Khaldûn, Tahqîq Majdî Fathî al-Sayyed. Mesir: Dâr alTaufiqiyah li al-Turâts.

Mahlani, G. (2013). Sintesa Pendidikan Islam. Makassar: LSQ.

Manti, B. B., Husaini, A., Mujahidin, E., \& Hafidhuddin, D. (2016). Konsep Pendidikan Modern Mahmud Yunus dan Kontribusinya Bagi Lembaga Pendidikan Islam di Indonesia. Jurnal Ta'dibuna, 5(2), 153-185.

Mattudala. (n.d.). "Manusia dan Kebudayaan Bugis-Makassar dan Kaili d Sulawesi” dalam Antropologi.

Mujahidin, E. (2005). Pesantren Kilat: Alternatif Pendidikan Agama Di Luar Sekolah. Jakarta: Pustaka al-Kautsar.

Muljana, S. (2008). Kesadaran Nasional, dari Kolonialisme sampai Kemerdekaan. Yogyakarta: LKiS.

Munawwir, I. (2006). Mengenal pribadi 30 pendekar dan pemikir Islam dari masa ke semasa. Bina Ilmu.

Noorduyn, J. (2000). "The Wajorese Merchants' Community in Makassar" dalam Roger Tol, Kees van Dijk dan. In G. Acciaioli (Ed.), Authority and Enterprise among the Peoples of South Sulawesi. Leiden: KITLV Press.

Palimai, I. K. (2010). Jejak Dakwah KH Lanre Said: Ulama Pejuang dari DI/TII hingga Era Reformasi. Jogjakarta: Aynat Publishing.

Patunru, A. D. (1965). Sedjarah Wajo. Makassar: YKSST.

Pawiloy, S. (1987). Sejarah Perjuangan Angkatan 45 di Sulawesi Selatan. Ujungpandang: Dewan Harian Daerah Angkatan 45.

Umar, H. (2000). Riset Sumber Daya Manusia dalam Organisasi (Vol. (Cet. III;). Jakarta: PT. Gramedia Pustaka Utama.

Yunus, M. (1996). Sejarah Pendidikan Islam di Indonesia. Jakarta: PT. Hidkarya Agung. 